\title{
Effect of Ambilhar (niridazole) on spermatogenesis in guinea-pigs
}

\author{
A. Etribi, A. Ibrahim, S. El-Haggar, H. Awad and B. Metawi \\ Department of Andrology, Faculty of Medicine, Cairo University, Cairo, Egypt
}

\begin{abstract}
Ambilhar is a new antibilharzial drug which will probably be widely used in Egypt. It is a nitrothiazole derivative and is related to metronidazole (Flagyl) and to nitrofurazone (Furacin). Administration of Ambilhar to host mice leads to destruction of the gonads of male and female schistosomes (Striebel \& Kradolpher, 1966), and to disruption of spermatogenesis in mice, rats and Japanese quail (Jones, Jackson \& Whiting, 1976). The aim of present work was to study the effect of Ambilhar on spermatogenesis in guinea-pigs since these were available to us.
\end{abstract}

Adult male guinea-pigs were allocated to two groups. Group A, of 20 animals, were given an oral dose of Ambilhar ( $50 \mathrm{mg} / \mathrm{kg} /$ day) for 5 consecutive days. The dose required was calculated from the weight of the animal and the excess material from the tablet $(0 \cdot 1 \mathrm{~g}: \mathrm{CIBA})$ was filed away. Testicular and epididymal biopsies were taken on the 5th and 8th days, then every week for 20 weeks. Biopsies were fixed in Bouin's solution, embedded in paraffin wax, cut into $8 \mu \mathrm{m}$ sections and stained with haematoxylin and eosin. The remaining 10 animals (Group B) served as controls.

Guinea-pigs displayed poor tolerance to Ambilhar (only 10 animals continued the experiment to the end) although rats (Lambert, Siniari \& Tripod, 1965; Jones et al., 1976) and mice (Jones et al., 1976) can tolerate a dose of $100 \mathrm{mg} / \mathrm{kg}$.

The earliest histological changes were seen on the 5th day: sperm numbers in some testicular tubules were reduced. By the 8 th day (Pl. 1, Fig. 1), the tubules varied in size and showed variable degrees of damage and inhibition of spermatogenesis. Fifteen days after the start of the experiment, some of the tubules had recovered completely and spermatozoa were again present (Pl. 1, Fig. 2). The epididymal biopsy of the same animal showed that there were a few tubules containing spermatozoa while the rest of the tubules were empty and collapsed (Pl. 1, Fig. 4, compare Pl. 1, Fig. 3). Biopsies from the 3 rd week onwards showed complete recovery of spermatogenesis, with spermatozoa appearing in nearly all tubules.

The marked inhibition of spermatogenesis which appeared by the 8th day was patchy in distribution, and areas showing maximal effect were close to those in which only slight changes could be seen. This patchy distribution was similar to that found in rats treated with nitrofuran (Prior \& Ferguson, 1950) and niridazole (Jones et al., 1976). Since the drug is presumably carried to the testis by the blood the distribution of the testicular blood vessels may account for the discontinuity of the lesion.

Lambert et al. (1965) found that inhibition of spermatogenesis in rats after treatment with $100 \mathrm{mg}$ Ambilhar $/ \mathrm{kg}$ /day started on the 5th day and was marked by the 10th day. Recovery started after 20 days, but was incomplete by the 30 th day. Similar results were reported by Jones et al. (1976) who also carried out fertility studies with mice and rats treated with niridazole, but even when fertility was recovered testicular damage was still observable. The rapid recovery of spermatogenesis in the guinea-pigs in the present study might have been due to the low dose of Ambilhar used, but rat testes were affected even by low doses of this drug (Jones et al., 1976).

The mode of action of Ambilhar is not yet fully known. However the glycogen content of the male worm has been shown, by specific enzymatic micromethods, to be decreased by Ambilhar treatment (Bueding \& Fisher, 1969), and was brought about by inhibition of phosphorylase inactivation, leading to the availability of more phosphorylase and increased degradation of glycogen. Because of a marked dependency of protein synthesis by spermatogenic cells on glucose (Davis, 1969), we suggest that Ambilhar, through its effect on glycogen degradation, may affect protein synthesis and thus subsequent inhibition of spermatogenesis. 


\section{References}

BUEDING, K. \& FISChER, J. (1969) Biochemical effects of schistomacides. Ann. N.Y. Acad. Sci. 160, 536543.

DAvis, J.R. (1969) Metabolic aspects of spermatogenesis. Biol. Reprod. 1, 93-118.

Jones, P., JACKSON, H. \& Whiting, M.H.S. (1976) Comparative effects of niridazole on spermatogenesis and reproductive capacity in the mouse, rat and Japanese quail. J. Reprod. Fert. 46, 217-224.
LAmberT, C.R., Siniari, V.S.P. \& Tripod, J. (1965) Effect of Ciba $32644 \mathrm{Ba}$ on spermatogenesis in laboratory animals. Acta trop. 22, 155-161.

Prior, J.J. \& Ferguson, J.H. (1950) Cytotoxic effect of Nitrofuran on the rat testis. Cancer 43, 1062.

Striebel, H.P. \& Kradolpher, F. (1966) Mode of action of Ciba 32,644-Ba in experimental schistosomiasis. Acta trop., Suppl. 9, 54-58.

Received 16 June 1976 
PLATE I
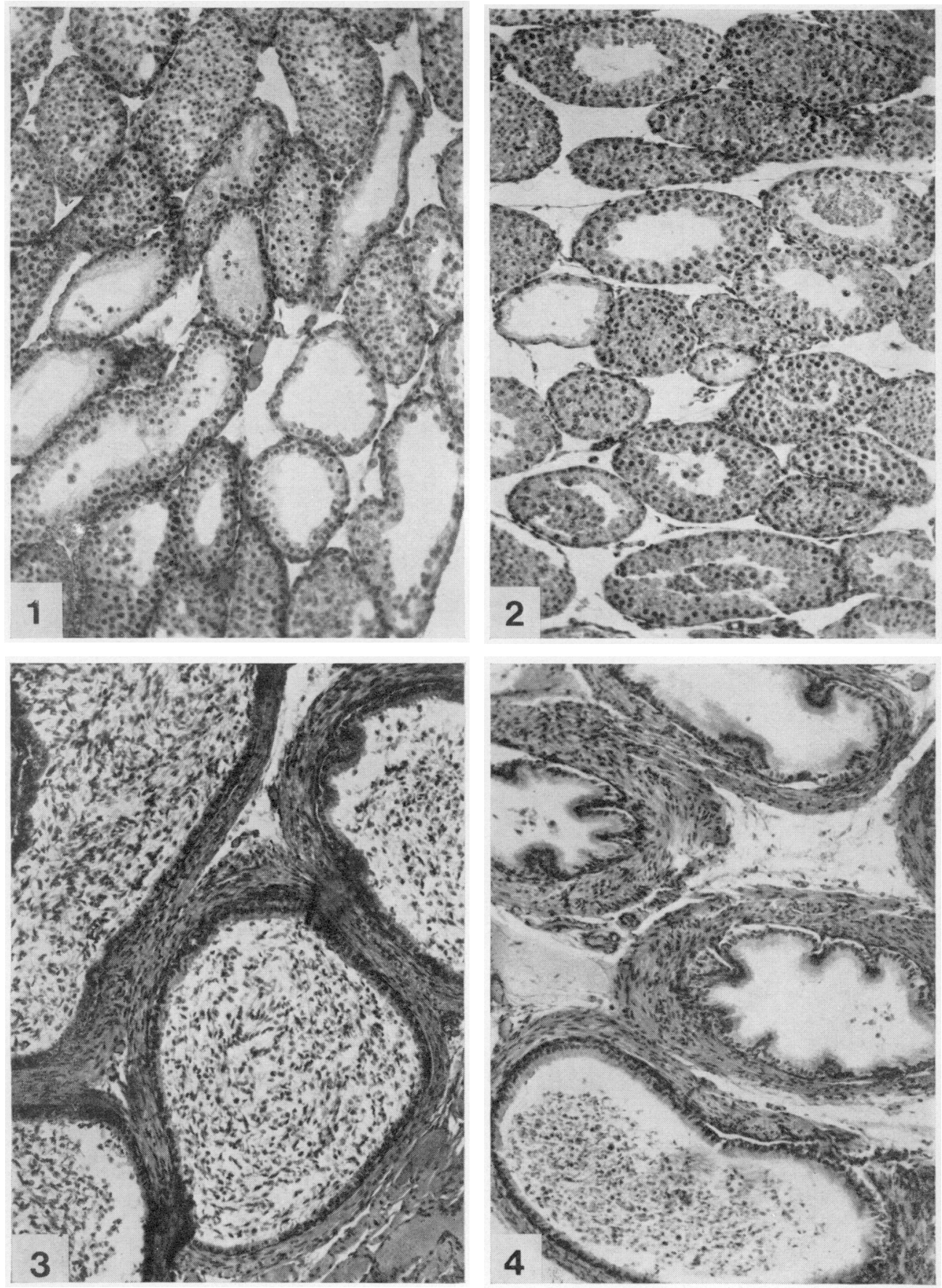

Testicular (Figs 1 and 2) and epididymal (Figs 3 and 4) biopsies of guinea-pigs treated with 50 mg Ambilhar kg day for 5 days.

Fig. 1. Biopsy 8 days after the start of treatment. The tubules are of various sizes and show variable degrees ol spermatogenic arrest. $\times 60$.

Fig. 2. Biopsy 15 days after the start of treatment. Notice the signs of recovery: some tubules contain spermatozoa while others show arrest at the primary or secondary spermatocyte or spermatogonial stage. $\times 60$.

Fig. 3. Biopsy taken 5 days after the start of treatment showing, distended tubules full of spermatozoa. $\times 60$

Fig. 4. Fpididymal biops of same guinea-pig as Fig. 2. All the tubules are empty and collapsed. Onls one lubule contains some spermatozoa but much detritus is present. $\times 60$. 